\author{
УДК 330.322:336 \\ JEL B400 \\ ORCID ID: 0000-0002-8311-1157 \\ DOI https://doi.org/10.17721/tppe.2020.40.1
}

Fyliuk G.M., Doctor of Economics, Professor, Taras Shevchenko National University of Kyiv Akulenko K.V., Ph.D. Student

Taras Shevchenko National University of Kyiv

\title{
ANALYSIS OF INVESTMENT ATTRACTIVENESS OF ENTERPRISES OF AGROINDUSTRIAL COMPLEX OF UKRAINE
}

A comparison of the main financial and economic indicators of agro-industrial enterprises engaged in the cultivation of oilseeds in Ukraine and the current trends in their development are determined. The analysis of investment attractiveness of domestic agro-industrial enterprises in cultivating oilseeds and the most investment-attractive domestic agro-industrial enterprises according to the results of the use of the method of graphic integration were engaged. Four variants of the integral indicator were calculated, provided that the investor's advantage is given to the market position and competitiveness of the company on the market, the profitability of the enterprise's activity, financial stability and independence, as well as the innovative potential of the investigated enterprise; the problems that cause the most negative impact on the level of their investment attractiveness were revealed and analyzed;a set of indicators that determine the investment attractiveness of the enterprise by the method of graphical integration were calculated; agricultural companies in three groups are analyzed: with high investment attractiveness, with average investment attractiveness and low investment attractiveness; the following general trends for all enterprises are highlighted:most of the indicators are in the middle and low attractiveness zone; the investment attractiveness graphs are approximately the same on a market position, mainly due to the influence of the external factor - the prevailing market demand; high profitability of sales due to the market situation; there is a potential very low innovation activity, almost no own development, using mostly borrowed innovation; high rates of financial sustainability, most enterprises carry out economic activities through self-financing, however, on the other hand, this indicates the problems related to the attraction of financing sources and lack of adequate support of the agro-industrial complex from the state the rating of investment attractiveness of domestic agro-industrial enterprises in cultivating oilseeds is constructed, in relation to different investor's goals, accordingly with the obtained values of the general integral coefficients were engaged.

Key words: investments, investment attractiveness of agroindustrial complex, investment attractiveness of the enterprise, rating of investment attractiveness, investment efficiency, investment attractiveness indicators, graphic integration method, general integral coefficient, innovations.

Formulation of the problem. Under current conditions, the activity of agro-industrial enterprises related to the cultivation of oilseeds in Ukraine is estimated as the most dynamically developing, is export-oriented and highly profitable.Thus, Ukraine is a leader in the production of sunflower seeds and sunflower oil in the world, it grew $28.3 \%$ of world sunflower seeds in 2019 ( 14.5 million tons). The main competitors of domestic products are Russia, which provides $25 \%$ of the world market, Europe - 19\%, Argentina 
- $6.8 \%$ and the United States, China, Turkey, South Africa, Serbia, Kazakhstan, which together provide about $15 \%$ of the market [15]. According to the results of 2019, the profitability of sunflower cultivation in Ukraine was $22.2 \%$ [9], which is one of the highest rates among the main domestic crops. These factors contribute to the constant increase in areas for oilseeds, increase capacity for oilseeds processing, strengthening the export position of the state, etc.

Getting high profits by domestic producers and processors of oilseeds over the past few years increases the interest of domestic farmers and foreign investors in the cultivation and processing of oilseeds in Ukraine. Therefore, this niche is relevant in terms of investment, and therefore requires careful study.

Analysis of recent research and publications. Problems related to the analysis and prospects of development of enterprises of the agro-industrial complex of Ukraine, their investment attractiveness have been studied in the works of many domestic and foreign scientists, in particular such as: T. V. Goloborodko, B.V. Dukhnytsky, S.O. Kushnir, N.V. Levchenko, T.V. Matsybora, A.M. Mykhailov, L.V. Moldavan, O.L. Musienko, V.V. Oglikh, S. P. Pentsak, O.V. Pimenova, N.P. Reznik, L.M. Rud, I.P. Sydorov, G.M. Fylyuk and others.

Unresolved parts of the problem. Despite quite in-depth research on this issue, some aspects, in particular those related to the development of a common methodology for analyzing the investment attractiveness of enterprises and the possibilities of its practical application in the agro-industrial complex of Ukraine, have not yet been resolved, remain controversial and need further study.

The purpose of the article is to analyze the investment attractiveness of agroindustrial enterprises of Ukraine engaged in oilseeds cultivation, according to a comprehensive methodology, which is based on the method of graphical integration to identify "weaknesses" and directions to increase the attractiveness of domestic agroindustrial enterprises to foreign investors.

Research results. To get a general idea of the level of the surveyed enterprises in terms of their attractiveness for investment, we built a table comparing the main financial and economic indicators of agro-industrial enterprises engaged in growing oilseeds in Ukraine in 2017 (Table 1). Preliminary analysis of investment attractiveness through the prism of financial indicators of agro-industrial enterprises in Ukraine engaged in growing oilseeds showed that among the surveyed enterprises there are several most attractive options for investing funds, in particular, investment-attractive enterprises include: Enselco Agro LLC, Sygnet LLC -Center ", PE" Yuts-Agroproduct Plus ", LLC" Urozhayna Kraiina ", LLC" Dniproagroalliance ". 
Table 1

Comparison of the main financial and economic indicators of agro-industrial enterprises engaged in the cultivation of oilseeds in Ukraine in 2017,

thousand UAH

\begin{tabular}{|c|c|c|c|c|c|c|c|c|c|c|c|}
\hline $\begin{array}{l}\text { № } \\
\mathrm{n} / \mathrm{n}\end{array}$ & Indicators & $\begin{array}{l}\text { "EnselkcoAgr } \\
\text { o" LLC }\end{array}$ & $\begin{array}{l}\text { "Sygnet- } \\
\text { Center" } \\
\text { LLC }\end{array}$ & $\begin{array}{c}\text { PJSC } \\
\text { "Nizhyn Fat } \\
\text { Factory" }\end{array}$ & $\begin{array}{l}\text { AgriculturalL } \\
\text { LC"Agroko" }\end{array}$ & $\begin{array}{l}\text { PE" Yuts- } \\
\text { Agroproduct } \\
\text { Plus " }\end{array}$ & $\begin{array}{l}\text { "Urozhayna } \\
\text { Kraiina" LLC }\end{array}$ & $\begin{array}{c}\text { PJSC } \\
\text { "Boguslav } \\
\text { Bread } \\
\text { Receiving } \\
\text { Enterprise" }\end{array}$ & $\begin{array}{l}\text { "Agricultural } \\
\text { EnterpriseAg } \\
\text { rodim" LLC }\end{array}$ & $\begin{array}{l}\text { Agricultural } \\
\text { LLC"Promin } \\
\text { " }\end{array}$ & $\begin{array}{c}\text { LLC" } \\
\text { Dniproagr } \\
\text { oalliance " }\end{array}$ \\
\hline 1 & Total income & 2381274,00 & $\begin{array}{c}1084 \\
893,00 \\
\end{array}$ & $\begin{array}{c}1003 \\
948,00\end{array}$ & 244127,00 & 850414,00 & 829879,00 & 254959,00 & 240458,00 & 652747,00 & $\begin{array}{c}248 \\
816,00\end{array}$ \\
\hline 2 & Operating profit & 860632,00 & $\begin{array}{c}432 \\
351,00 \\
\end{array}$ & 61236,00 & 38071,00 & 285706,00 & 246635,00 & 86276,00 & 13869,00 & 49560,00 & 96082,00 \\
\hline 3 & Net profit (net loss) & 858960,00 & $\begin{array}{c}404 \\
579,00\end{array}$ & 43820,00 & 30397,00 & 279897,00 & 246582,00 & $-22355,00$ & 469,00 & 48585,00 & 96082,00 \\
\hline 4 & $\begin{array}{l}\text { Balance sheet total } \\
\text { (total assets) }\end{array}$ & 4222728,00 & $\begin{array}{c}1377 \\
623,00 \\
\end{array}$ & $\begin{array}{c}1268 \\
832,00 \\
\end{array}$ & 304606,00 & $\begin{array}{r}1179 \\
450,00 \\
\end{array}$ & $\begin{array}{c}1010 \\
155,00 \\
\end{array}$ & 307793,00 & 843888,00 & $\begin{array}{c}1567 \\
820,00 \\
\end{array}$ & $\begin{array}{c}264 \\
317,00 \\
\end{array}$ \\
\hline 5 & Fixed assets & 108392,00 & $\begin{array}{c}371 \\
082,00 \\
\end{array}$ & 260555,00 & 189467,00 & 446539,00 & 208791,00 & 85168,00 & 172940,00 & 7248,00 & 32231,00 \\
\hline 6 & Long-term assets & 105257,00 & $\begin{array}{c}370 \\
921,00\end{array}$ & 220006,00 & 162995,00 & 16408,00 & 126681,00 & 76062,00 & 155706,00 & 7004,00 & 32210,00 \\
\hline 7 & Current assets & 4114336,00 & $\begin{array}{c}1006 \\
541,00\end{array}$ & $\begin{array}{c}1008 \\
277,00 \\
\end{array}$ & 115139,00 & 732911,00 & 801364,00 & 222625,00 & 670948,00 & $\begin{array}{c}1560 \\
572,00 \\
\end{array}$ & $\begin{array}{c}232 \\
086,00 \\
\end{array}$ \\
\hline 8 & $\begin{array}{l}\text { Cash and cash } \\
\text { equivalents }\end{array}$ & 13,00 & $\begin{array}{c}51 \\
344,00 \\
\end{array}$ & 543,00 & 672,00 & 2824,00 & 310,00 & 677,00 & 3615,00 & 2381,00 & 23026,00 \\
\hline 9 & Equity & 2078946,00 & $\begin{array}{c}1241 \\
487,00\end{array}$ & $-745519,00$ & 262038,00 & 527938,00 & 862392,00 & $-431127,00$ & 48321,00 & 200101,00 & $\begin{array}{c}178 \\
822,00\end{array}$ \\
\hline 10 & Statute capital & 7965,00 & $\begin{array}{c}100 \\
000,00\end{array}$ & 103107,00 & 16585,00 & 1,00 & 35000,00 & 50,00 & 1500,00 & 35,00 & 1000,00 \\
\hline 11 & $\begin{array}{l}\text { Long-term } \\
\text { obligations }\end{array}$ & 0 & $\begin{array}{c}37 \\
422,00 \\
\end{array}$ & 1105,00 & 580,00 & 0 & 0 & 0 & 619033,00 & 0 & 66700,00 \\
\hline 12 & $\begin{array}{l}\text { Long-term loans and } \\
\text { borrowings }\end{array}$ & 0 & $\begin{array}{c}31 \\
283,00\end{array}$ & 0 & 0 & 0 & 0 & 0 & 0 & 0 & 0 \\
\hline
\end{tabular}


Continuation of table 1

\begin{tabular}{|c|c|c|c|c|c|c|c|c|c|c|c|}
\hline 13 & Short-term obligations & $\begin{array}{c}2143 \\
782,00\end{array}$ & $\begin{array}{c}98 \\
714,00\end{array}$ & $\begin{array}{c}2013 \\
246,00\end{array}$ & 41988,00 & 651512,00 & 147763,00 & 738920,00 & 176534,00 & $\begin{array}{c}1367 \\
719,00\end{array}$ & 18795,00 \\
\hline 14 & $\begin{array}{l}\text { Short-term loans and } \\
\text { borrowings }\end{array}$ & 0 & 9313,00 & $\begin{array}{c}1035 \\
068,00\end{array}$ & 22659,00 & 0 & 0 & 619539,00 & 88900,00 & 7862,00 & 0 \\
\hline 15 & $\begin{array}{l}\text { Return of assets } \\
(\mathrm{ROA}), \%\end{array}$ & 20,34 & 29,37 & 3,45 & 9,98 & 23,73 & 24,41 & $-7,26$ & 0,06 & 3,10 & 36,35 \\
\hline 16 & $\begin{array}{l}\text { Return on capital } \\
\text { (ROE), \% }\end{array}$ & 41,32 & 32,59 & $-5,88$ & 11,60 & 53,02 & 28,59 & 5,19 & 0,97 & 24,28 & 53,73 \\
\hline 17 & $\begin{array}{l}\text { Return of sales (ROS), } \\
\%\end{array}$ & 39,48 & 38,33 & 5,08 & 13,07 & 51,38 & 34,98 & $-13,44$ & 0,20 & 7,72 & 39,52 \\
\hline 18 & $\begin{array}{l}\text { Operating profitability } \\
(\%)\end{array}$ & 39,55 & 40,96 & 7,10 & 16,36 & 52,45 & 34,99 & 51,87 & 5,97 & 7,87 & 39,52 \\
\hline 19 & Currentliquidityratio & 1,92 & 10,20 & 0,50 & 2,74 & 1,12 & 5,42 & 0,30 & 3,80 & 1,14 & 12,35 \\
\hline 20 & Rapid liquidity ratio & 1,66 & 8,55 & 0,43 & 0,87 & 0,96 & 4,93 & 0,13 & 3,16 & 0,99 & 11,94 \\
\hline 21 & Debt ratio, \% & 0 & 3,27 & $-138,84$ & 8,65 & 0 & 0 & -144 & 183,98 & 3,93 & 0 \\
\hline 22 & $\begin{array}{l}\text { Financial stability ratio, } \\
\%\end{array}$ & 96,98 & 911,95 & $-37,01$ & 615,58 & 81,03 & 583,63 & $-58,35$ & 6,07 & 14,63 & 209,16 \\
\hline 23 & $\begin{array}{l}\text { Growth rate of total } \\
\text { income, } \%\end{array}$ & $-16,01$ & 13,02 & 403,95 & 47,90 & 80,93 & 28,19 & $-24,75$ & 16,55 & 199,00 & 47,94 \\
\hline 24 & $\begin{array}{l}\text { The growth rate of } \\
\text { operating income, } \%\end{array}$ & $-30,36$ & 10,65 & 31,39 & $-9,21$ & 15,51 & $-12,14$ & $-13,53$ & $-40,59$ & $-74,33$ & 7,83 \\
\hline 25 & $\begin{array}{l}\text { Net profit growth rate, } \\
\%\end{array}$ & $-30,26$ & 10,78 & $-6,21$ & $-2,93$ & 13,17 & $-12,10$ & $-83,92$ & $-96,73$ & $-74,71$ & 7,83 \\
\hline
\end{tabular}

Note. Compiled and calculated by the author according to the data of enterprises 
To determine the most attractive for investment enterprise it's necessary to carry out further in-depth analysis of the enterprise, which necessitates the use of the method of graphical integration. The application of this method for the analysis of domestic agroindustrial enterprises engaged in the cultivation of oilseeds, allows you to evaluate additionally the market position of enterprises, the level of riskiness of their activities, as well as the innovative component in the activities of agricultural enterprises.

After calculating a set of indicators that determine the investment attractiveness of the enterprise by the method of graphical integration, for better perception of information agricultural companies were divided into three groups: with high investment attractiveness, medium investment attractiveness and low investment attractiveness.

The group of companies determined by high investment attractiveness includes: Sygnet-Center LLC, Urozhayna Kraina LLC, Dniproagroalliance LLC.

The group of companies determined by the average investment attractiveness includes: Enselco Agro LLC, Agricultural LLC Agroko, PE Yuts Agroproduct Plus, Agricultural LLC Promin.

The group of companies characterized by low investment attractiveness includes: PJSC "Nizhyn Fat Factory", "Agricultural Enterprise Agrodim LLC", PJSC "Boguslav Bread Receiving Enterprise".

A comparison of the most investment-attractive domestic agro-industrial enterprises based on the results of using the method of graphical integration is shown on Figure $1 .$.

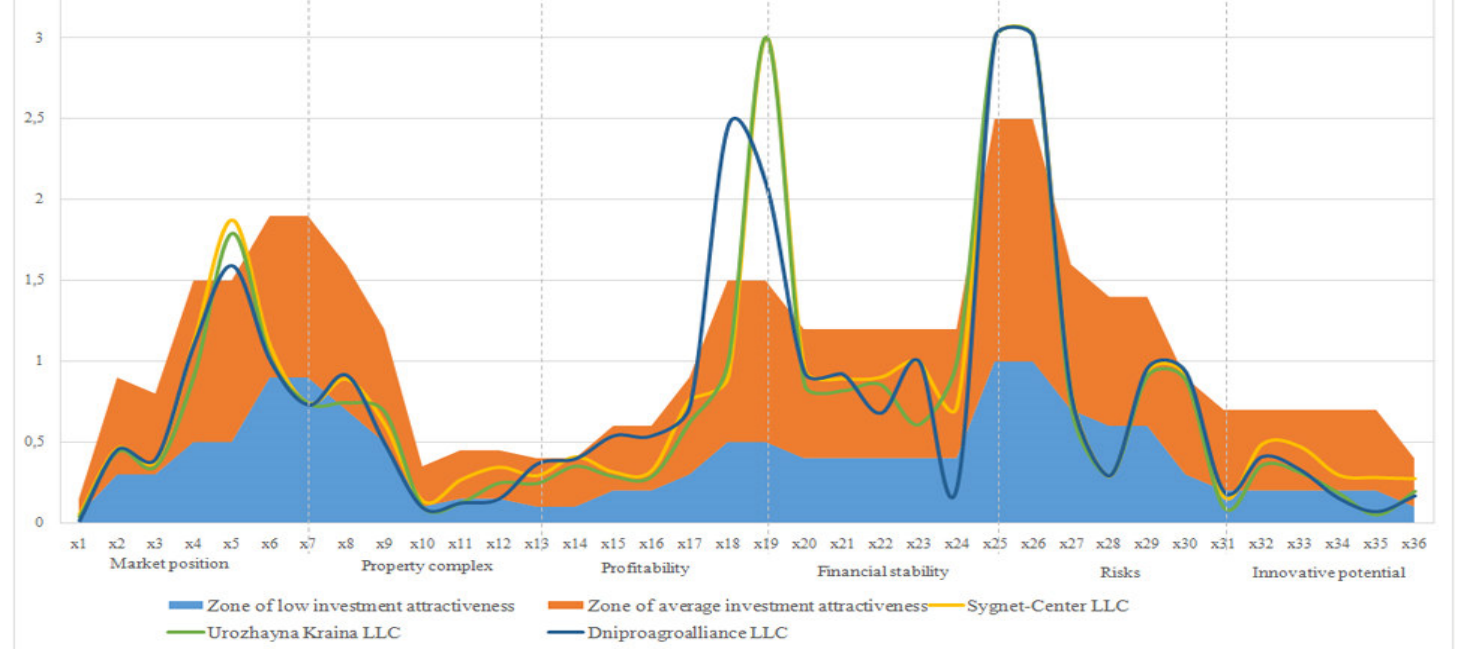

Figure 1. Comparison of the most investment-attractive domestic agro-industrial enterprises based on the results of using the method of graphical integration

Note. Created by the author on the basis of his own calculations

As can be seen from Figure 1, in general, the most attractive investment is the company LLC "Sygnet-Center", as the vast majority of indicators are higher than have other companies, and the graph is almost entirely in the zone of medium attractiveness, crossing the zone of low investment attractiveness only at "property complex," as well as approaching the minimum values of the zone of average attractiveness in two more points - in the risk zone and in the zone, again, of the property complex. 
In addition, the analyzed company is partly lies in the plane of high investment stability on some indicators of market position, profitability and financial stability.

Urozhayna Kraina LLC and Dniproagroalliance LLC also have good indicators and are mostly in the zone of average investment attractiveness, but have worse indicators: their investment attractiveness curve is lower and more often approaches and crosses the zone of low investment attractiveness.

Comparisons of domestic agro-industrial enterprises that have an average investment attractiveness based on the results of using the method of graphical integration are shown in Figure 2.

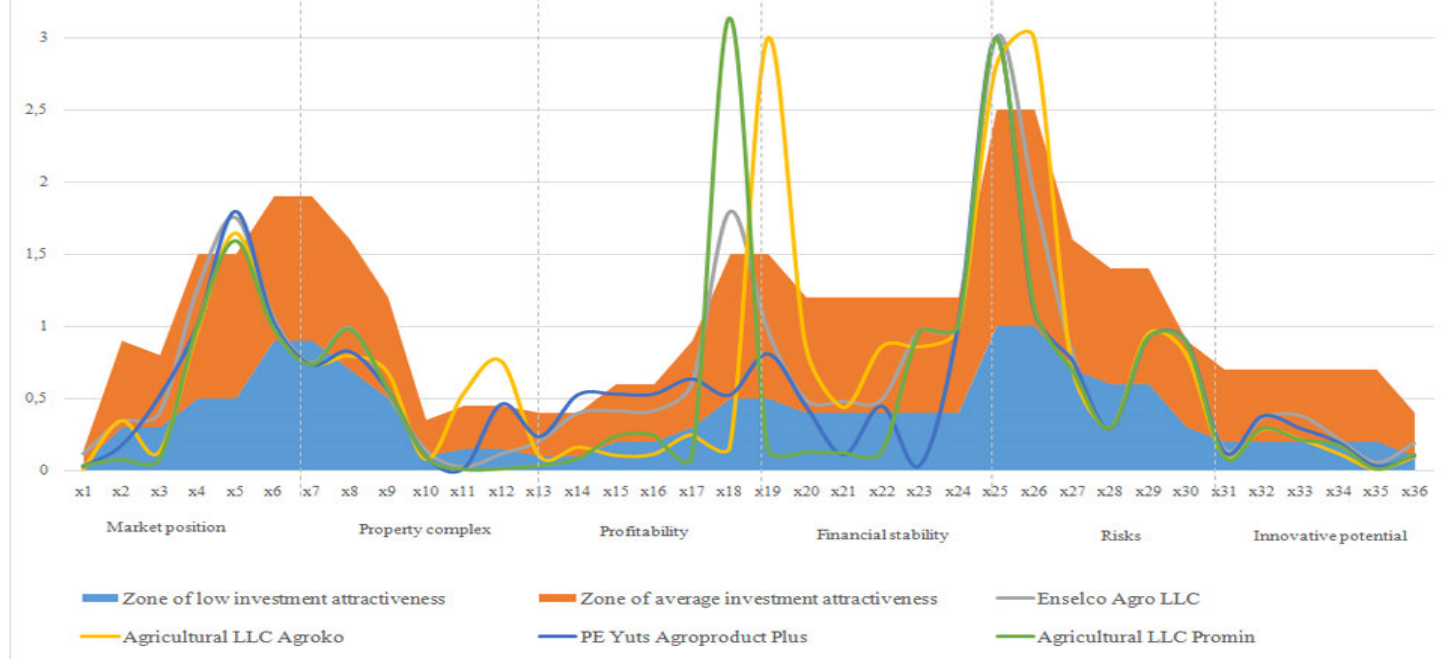

Figure 2. Comparison of domestic agro-industrial enterprises that have an average investment attractiveness based on the results of using the method of graphical integration

Note. Created by the author on the basis of his own calculations.

From Figure 2 we can note the following general trends for all enterprises:

- most indicators are in the zone of medium and low attractiveness;

- Investment attractiveness graphs on the market position's zone are approximately the same, this is mainly due to the influence of external factors prevailing market demand for example. Domestic processing companies do not currently use $25 \%$ of their extraction capacity, and the deficit of sunflower seeds is about 3 million tons [10];

- high profitability of sales, which is due to the above market situation;

- the potential of innovative activity of enterprises is very low, own developments are almost absent, mostly borrowed innovations are used;

- high indicators of financial stability, most enterprises carry out economic activities through self-financing, however, on the other hand, this indicates problems related to attracting credit sources of funding and the lack of proper support of the agro-industrial complex by the state.

Comparison of domestic agro-industrial enterprises with low investment attractiveness based on the results of using the method of graphical integration is shown in Figure 3.

As we can see from the graphs of investment attractiveness of these enterprises, some indicators are even lower than the low investment attractiveness, which indicates losses in 
the activities of enterprises or high debt on credit resources, and therefore financial instability and bankruptcy in the worst case. The least attractive is the area of innovation of enterprises, almost all indicators are below the average investment attractiveness.

The next stage of the method of studying the investment attractiveness of enterprises is to determine the quantitative level of investment attractiveness using a generalizing indicator - the integrated coefficient of investment attractiveness of the enterprise, which is calculated by numerical integration, in particular, the method of rectangles. The calculation of this coefficient makes it possible to determine the rating of enterprises by the level of investment attractiveness and choose the most attractive option for investment. In addition, using the method of numerical integration, it is possible to take into account the value of weight of each coefficient (or group of coefficients), in order to give preference to certain indicators, depending on the goals of the investor.

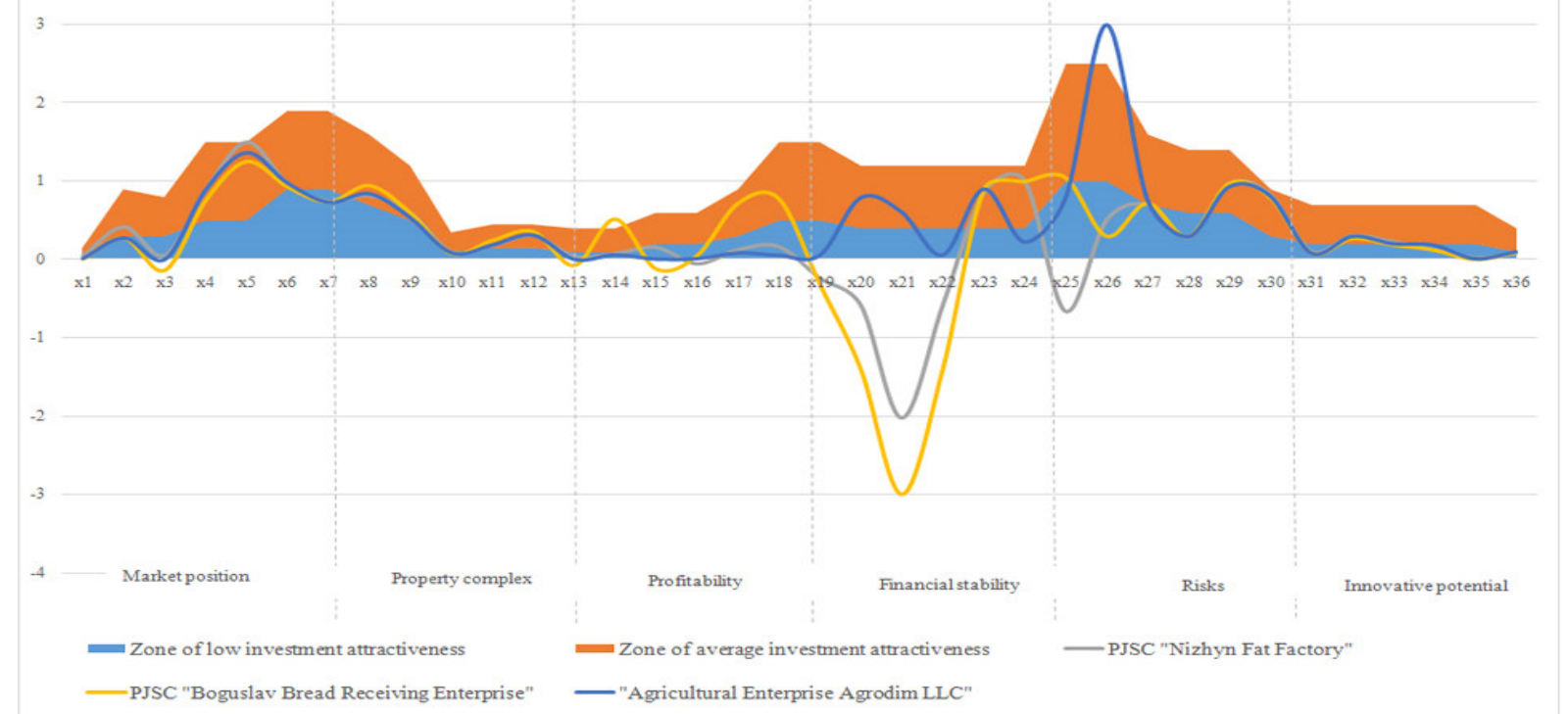

Figure 3. Comparison of the least investment-attractive domestic agro-industrial enterprises based on the results of using the method of graphical integration

Note. Created by the author on the basis of his own calculations

In addition to the standard integrated indicator, we calculated four more variants of the same indicator, but on the conditions that the investor's preference is given to the market position and competitiveness of the enterprise on the market, profitability, financial stability and independence, and also to innovation potential of the researched enterprise. According to the results of the calculations, the ratings of enterprises were compiled, which is shown on Table 2.

It should be noted that according to the formula for calculation by the method of rectangles $a=h \times i$, " $h$ " is actually the weighting coefficient for each indicator is equal to 1 , and "l" is actually the number of indicators equal to 36 . That is, the segment on which the graphs of investment attractiveness are built has a maximum length of 36 units. This is important for the rational calculation of the integral coefficient, because by changing the value, for example, h1 to more or less (depending on the bigger or smaller weight of the indicator), the sum h1...h36 must be equal to 36 , otherwise the calculations will be incorrect. The connections between all groups of indicators, and the value of the integrated 
indicator of investment attractiveness will not correlate with an area of figure under the graph of investment attractiveness of the enterprise.

In our case, when analyzing changes in the level of investment attractiveness of the enterprise, the weighting coefficient was used for the whole group of indicators, where h1 - the same weighting coefficient for each of the indicators of analysis group of the market position of enterprise, h2 - property complex respectively, h3 - profitability of enterprise, h4 - financial sustainability, h5 - the level of risk of investing in the enterprise, h6 innovation potential. The total value of $\mathrm{h} 1 \ldots \mathrm{h} 36$ corresponds to the equality $\mathrm{a}=6 \times \mathrm{h} 1+$ $6 \times h 2+6 \times h 3+6 \times h 4+6 \times h 5+6 \times h 6=36(6$ - the number of indicators in each group of analysis).

So, as we see, according to the results of calculating the standard integrated coefficient of investment attractiveness of the enterprise, when all groups of indicators for the investor have the same weight ( $h 1=1, h 2=1, h 3=1, h 4=1, h 5=1, h 6=1)$, the most attractive is the company "Sygnet-Center" LLC, the value of the overall indicator is 29.11 , and the least attractive is PJSC "Boguslav Bread Receiving Enterprise", the value of the integrated coefficient of investment attractiveness in 2016 was 8.52.

Now let's analyze the options when the most important for the investor is the competitive position of the company on the market, and the least interests are in the indicators of the property complex, risks and innovation potential ( $h 1=2.5, \mathrm{~h} 2=0.5, \mathrm{~h} 3=1, \mathrm{~h} 4=1, \mathrm{~h} 5=$ $0.5, \mathrm{~h} 6=0.5$ ). Calculations show that the leader's position on terms of investment attractiveness has not changed, and the value of the integrated indicator has increased even more to 29.92. However, other changes took place, Agroko LLC moved to a rating from 4 to 5 due to the reduction of the integral indicator of the investment attractiveness ratio to 24.69, and the integrated indicator of PJSC "Boguslav Bread Receiving Enterprise" increased to 9.33 , but not gave the company the opportunity to rise in the rankings from the last position.

In the case when for the investor is most important profitability of the enterprise, and the least interests are in the indicators of the property complex, risks and innovation potential ( $\mathrm{h} 1=1, \mathrm{~h} 2=0.5, \mathrm{~h} 3=2.5, \mathrm{~h} 4=1, \mathrm{~h} 5=0.5, \mathrm{~h} 6=0.5$ ), the leader was taken by the company LLC "Dniproagroalliance" with a total value of 29.29 against 26.95 in LLC "Sygnet-Center". Positions at the end of the rating have also changed, now the most unattractive company on terms of investment is the company PJSC "Nizhyn Fat Factory" with a rate of 6.52 .

On terms of importance for the investor of the financial stability of the enterprise, and the least interest in the indicators of the property complex, risks and innovation potential ( $h 1=1, h 2=0.5, h 3=1, h 4=2.5, h 5=0.5, h 6=0.5$ ), the leadership again belongs to "Sygnet-Center" LLC, and the value of the integrated indicator of the enterprise is even higher than the standard - 33.64, which shows a significant advantage over other enterprises on terms of financial stability. While PJSC "Boguslav Bread Receiving Enterprise", on the contrary, demonstrates complete financial instability and dependence on credit sources (-1.66). 
Table 2 Rating and values of the general integrated coefficients of investment attractiveness of the domestic agro-industrial enterprises which are engaged in cultivation of oil seeds crops, according to various purposes of the investor

\begin{tabular}{|c|c|c|c|c|c|c|c|c|c|c|}
\hline Indicators & $\begin{array}{c}\text { "Sygne } \\
t \\
\text { Center" } \\
\text { LLC }\end{array}$ & $\begin{array}{c}\text { "Dnipr } \\
\text { oagroa } \\
\text { lliance" } \\
\text { LLC }\end{array}$ & $\begin{array}{l}\text { "Urozhayn } \\
\text { aKraiina" } \\
\text { LLC }\end{array}$ & $\begin{array}{l}\text { "Agricult } \\
\text { ural LLC } \\
\text { Agroko" }\end{array}$ & $\begin{array}{l}\text { "Ensel } \\
\text { co } \\
\text { Agro" } \\
\text { LLC }\end{array}$ & $\begin{array}{c}\text { PE" } \\
\text { Yuts- } \\
\text { Agropro } \\
\text { duct } \\
\text { Plus }\end{array}$ & $\begin{array}{c}\text { Agricultu } \\
\text { ralLLC"P } \\
\text { romin" }\end{array}$ & $\begin{array}{l}\text { "Agricult } \\
\text { ural } \\
\text { Enterpri } \\
\text { seAgrod } \\
\text { im" LLC }\end{array}$ & $\begin{array}{c}\text { PJSC } \\
\text { "Nizhyn } \\
\text { Fat } \\
\text { Factory" }\end{array}$ & $\begin{array}{c}\text { PJSC } \\
\text { "Bogus } \\
\text { lav } \\
\text { Bread } \\
\text { Receivi } \\
\text { ng } \\
\text { Enterpr } \\
\text { ise" }\end{array}$ \\
\hline $\begin{array}{l}\text { 1.Under conditions of equal weight of indicators ( } h 1=1, h 2=1 \text {, } \\
h 3=1, h 4=1, h 5=1, h 6=1 \text { ) }\end{array}$ & 29,11 & 27,99 & 26,86 & 24,93 & 24,89 & 21,12 & 20,16 & 16,40 & 8,80 & 8,52 \\
\hline Rating 1 & 1 & 2 & 3 & 4 & 5 & 6 & 7 & 8 & 9 & 10 \\
\hline $\begin{array}{l}\text { 2. Under conditions of the importance of the market position of } \\
\text { the enterprise ( } h 1=2,5, h 2=0,5, h 3=1, h 4=1, h 5=0,5, h 6=0,5)\end{array}$ & 29,92 & 28,60 & 27,57 & 24,69 & 26,40 & 22,63 & 20,82 & 16,72 & 11,56 & 9,33 \\
\hline Rating 2 & 1 & 2 & 3 & 5 & 4 & 6 & 7 & 8 & 9 & 10 \\
\hline $\begin{array}{l}\text { 3.Under conditions of the importance of the profitability of the } \\
\text { enterprise( } h 1=1, h 2=2,5, h 3=1, h 4=0,5, h 5=0,5, h 6=0,5)\end{array}$ & 26,95 & 29,29 & 24,93 & 19,88 & 24,74 & 20,28 & 20,88 & 11,75 & 6,52 & 7,50 \\
\hline Rating 3 & 2 & 1 & 3 & 7 & 4 & 6 & 5 & 8 & 10 & 9 \\
\hline $\begin{array}{l}\text { 4. Under conditions of the importance of financial stability of the } \\
\text { enterprise }(h 1=1, h 2=1, h 3=2,5, h 4=0,5, h 5=0,5, h 6=0,5)\end{array}$ & 33,64 & 30,53 & 31,45 & 29,03 & 25,62 & 20,09 & 18,90 & 15,38 & 3,40 & $-1,66$ \\
\hline Rating 4 & 1 & 3 & 2 & 4 & 5 & 6 & 7 & 8 & 9 & 10 \\
\hline $\begin{array}{l}\text { 5. Under conditions of the importance of the innovative potential } \\
\text { of the enterprise ( } h 1=1, h 2=1, h 3=1, h 4=0,5, h 5=0,5, h 6=2,5)\end{array}$ & 23,89 & 22,13 & 20,86 & 18,14 & 19,26 & 15,80 & 15,05 & 11,41 & 5,54 & 4,66 \\
\hline Rating 5 & 1 & 2 & 3 & 5 & 4 & 6 & 7 & 8 & 9 & 10 \\
\hline Averagerating & 1,2 & 2 & 2,8 & 5 & 4,4 & 6 & 6,6 & 8 & 9,2 & 9,8 \\
\hline
\end{tabular}

Note. Created and calculated by the author according to enterprises 
In the latter case, when the investor hopes for an innovative component at the activity of enterprise, and expresses the least interest at the indicators of the property complex, risks and market position ( $\mathrm{h} 1=0.5, \mathrm{~h} 2=0.5, \mathrm{~h} 3=1, \mathrm{~h} 4=1, \mathrm{~h} 5=0.5, \mathrm{~h} 6=2.5$ ), the leading positions again belong to Sygnet Center LLC. However, in this case, we should pay attention to the general integrated indicators of all enterprises, in this area of investment interest, they have decreased significantly, so the value of the integrated indicator of the leading enterprise is 23.89 , and the outsider is 4.66 .

This indicates that innovation is not a "strength party" at the activities of domestic agroindustrial enterprises, and, therefore, it is essential to develop serious measures to improve and increase the level of innovation potential of industrial enterprises.

In general, according to the average value of the ratings, we can conclude that the company LLC "Signet-Center" has confirmed its leadership position among the surveyed agro-industrial enterprises, going down to second place only on terms of profitability.

Graphically and more detailed the changes of the integrated coefficients of investment attractiveness of domestic agro-industrial enterprises engaged in the cultivation of oilseeds, in accordance with the various objectives of the investor are shown on Figure 4.

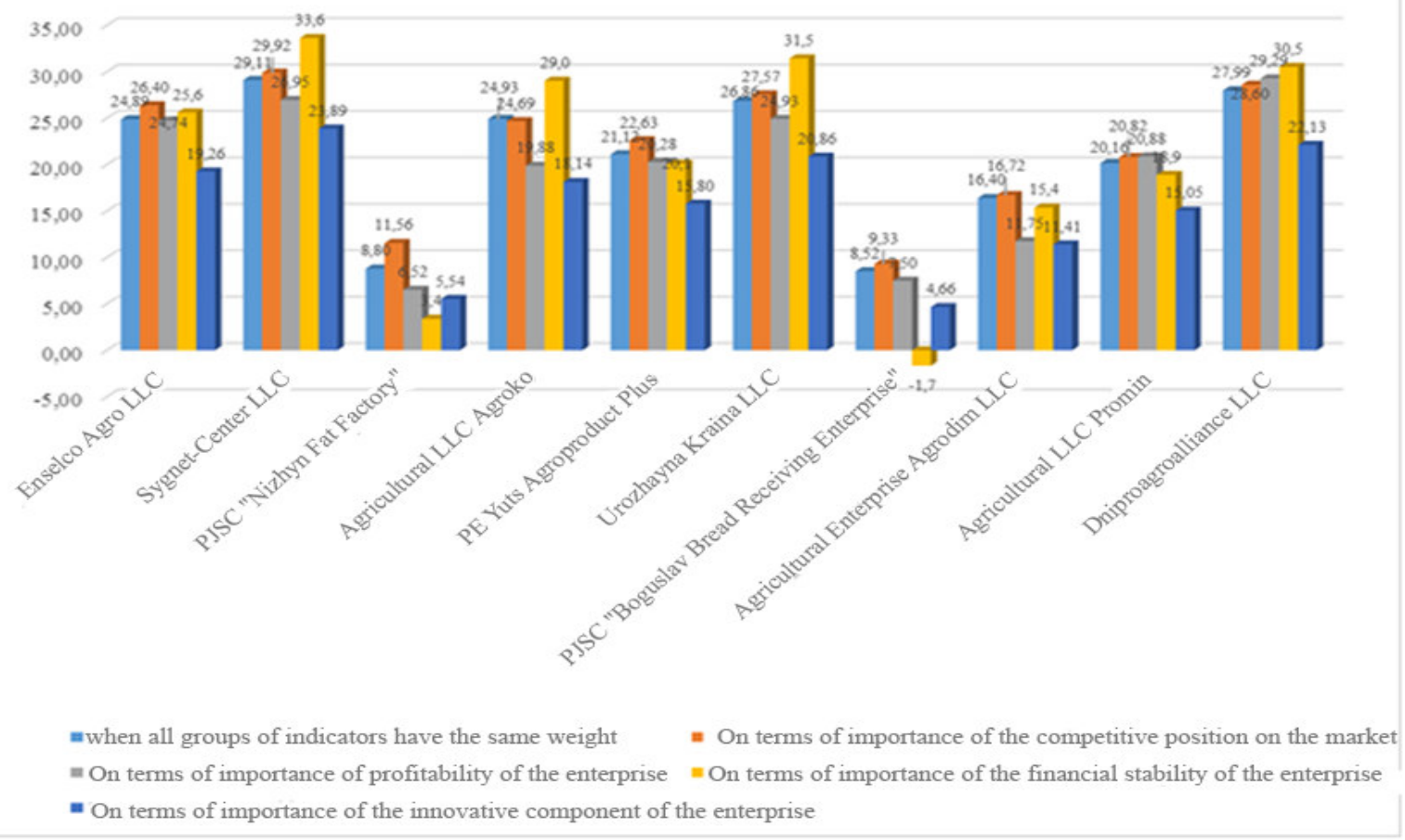

Figure 4. Changes of the integrated coefficients of investment attractiveness of domestic agroindustrial enterprises engaged in the cultivation of oilseeds, in accordance with different goals of the investor

Note. Created by the author on the basis of his own calculations

Thus, as a result of the analysis of investment attractiveness of domestic agro-industrial enterprises engaged in growing oilseeds, we can conclude that, on the background of the general investment attractiveness of the agro-industrial sector of Ukraine under current conditions, and, in particular, growing oilseeds by enterprises, there are a number of problems, which prevents companies from active developing to increase production and innovation potential. 
First of all, this is confirmed by studies of the financial support of agro-industrial enterprises, which show that enterprises mostly work at the expense of their own resources.Although the share of self-financing of economic activity of agricultural enterprises is significant, it is not enough to meet all needs, so there is a problem of lending to domestic agricultural enterprises and non-participation of the state in the development of an important and advanced branch of industry today.

Conclusions. Growing of oilseeds is an important part of Ukraine's economic development strategy. In the last ten years, there has been a steady trend of expanding the sown area of oilseeds by domestic agricultural enterprises due to increased economic efficiency of their cultivation compared to other crops. In particular, the demand for sunflower seeds in Ukraine will continue to increase due to the growth of processing capacity, while the prospect of expanding the rapeseed market is due to the favorableness of these crops to Ukrainian soils, as well as the using of rapeseed oil for biodiesel production. Soybean crops have the prospect of expansion by increasing their area on irrigated lands in the southern regions of Ukraine, which will form a "soybean belt" of stable production [10].

The interest of foreign investors in the agricultural resources of our country is also confirmed by the fact that in recent years the presence of foreigners in the land lease market of Ukraine is increasing. Researchers of the University of Auckland in New Zealand have found that more than 2.2 million hectares, or about $5.3 \%$, of Ukraine's agricultural land is currently controlled by foreign companies. Among the main market players are companies from Denmark (Trigon Agri), Saudi Arabia, France and the United States, as well as mixed domestic and foreign companies with the participation of Cyprus, Austria, Luxembourg [14]. This means that domestic agro-industrial enterprises have a very important resource for the development of their activities and economic growth.

Therefore, a necessary condition for the strategic development of domestic agroindustrial production is to identify such socio-economic, organizational, legal and environmental levers to increase the investment attractiveness of agricultural enterprises in Ukraine, which will promote effective and rational development of the industry and its transition to innovative level of functioning.

\section{References}

1. Asociaciya «Ukroliyaprom». Za ocinkamy" USDA Ukrayina zaly shayet'sya u 2020/21 MR svitovy'm liderom z vy'robny'cztva ta eksportu oliyi sonyashny'kovoyi ta shrotu. - Rezhy'm dostupu: https://msb.aval.ua/news/?id=25886

2. Goloborod'ko T. V. Doslidzhennya rozvy tku ta investy cijnoyi pry` vably`vosti agrarnoyi sfery` Ukrayiny' / T. V. Goloborod'ko // AgroSvit. - 2015. - \# 2. - C. 30-35.

3. Duxny'cz'ky’j B. V. Perspekty`vy' investuvannya agrarnogo sektoru Ukrayiny' inozemny'my' kompaniyamy` / B. V. Duxny`cz’ky”j // Ekonomika APK. - 2012. - \# 10. - C. 126-131.

4. Levchenko N. V. Metody' ocinyuvannya investy cijnoyi pry'vably'vosti sil's'kogo gospodarstva regioniv Ukrayiny' v konteksti strategichnogo planuvannya / N. V. Levchenko, V. V. Oglix // Aktual'ni problemy`ekonomiky”. - 2012. - \# 8. - C. 285-293.

5. Macy 'bora T. V. Svitovy’j dosvid u polipshenni investy 'cijnoyi pry`vably vosti agrarnogo sektoru Ukrayiny` / T. V. Macy`bora // Ekonomika APK. - 2017. - \# 7. - C. 101-105. 
6. My'xajlov A. M. Metody'chni pidxody` ta sy`stema pokazny`kiv vy’znachennya investy'cijnogo klimatu v agrarnomu sektori ekonomiky` / A. M. My’xajlov // Ekonomika APK. - 2016. - \# 12. - C. 76-83.

7. Moldavan L. V. Superechnosti zemel'noyi reformy` v agrarnomu sektori Ukrayiny` v konteksti svitovoyi prakty 'ky' / L. V. Moldavan // Ekonomika i prognozuvannya. - 2016. - \# 2. - S. 148-159. Rezhy`m dostupu: http://nbuv.gov.ua/UJRN/econprog_2016_2_11

8. Musiyenko O. L. Problemy' ta shlyaxy' pidvy'shhennya investy'cijnoyi pry'vably'vosti pidpry`yemstv agrarnogo vy'robny'cztva / O. L. Musiyenko // Strategichni napryamky` social'noekonomichnogo rozvy'tku derzhavy` v umovax globalizaciyi. - 2013. - C. 304-307.

9. Nazvana samaya rentabel'naya sel'xozkul'tura v 2019 [Elektronny’j resurs] // Latifundist - 2019. - Rezhy'm dostupu do resursu: https://latifundist.com/novosti/48425-nazvana-samaya-rentabelnayaselhozkultura-v-2019-g

10. Novi mozhly'vosti Ukrayiny' na svitovomu ry'nku olijny'x kul'tur [Elektronny'j resurs] // Nezalezhny j chlen mizhnarodnoyi merezhi Baker Tilly International. - 2017. - Rezhy'm dostupu do resursu: http://www.bakertilly.ua/news/id1189.

11. Penczak S. P. Metody'chni pidxody' do ocinyuvannya investy`cijnoyi pry`vably'vosti agrarny'x pidpry yemstv / S. P. Penczak // Ekonomika ta derzhava. - 2012. - \# 5. - C. 98-100.

12. Reznik N. P. Pidvy'shhennya investy'cijnoyi pry'vably'vosti pidpry`yemstv APK - peredumova zaluchennya inozemny`x investy`cij / N. P. Reznik // Formuvannya ry`nkovy`x vidnosy`n v Ukrayini. 2012. - \# 9. - C. 88-92.

13. Rud` L. M. Investy`cijna pry`vably`vist` agropromy`slovogo kompleksu Ukrayiny`: suchasny`j stan ta perspekty`vy' [Elektronny`j resurs] / L. M. Rud', S. O. Kushnir // Problemy` sy`stemnogo pidxodu v ekonomici. - 2017. - Vy’p. 1. - S. 42-46.

14. Sy'dorov I. P. Metody'chni pidxody' ocinyuvannya investy'cijnoyi pry`vably'vosti agropromy’slovogo vy'robny`cztva / I. P. Sy`dorov // Investy’ ciyi: prakty`ka ta dosvid. - 2017. - \# 15. - C. 57-61.

15. Urozhajnost 'podsolnechny'ka v Ukray'ne na $44 \%$ bol'she, chem v Rossy'y'. Latifundist. Rezhy'm dostupu: https://latifundist.com/novosti/48341-urozhajnost-podsolnechnika-v-ukraine-na-44bolshe-chem-v-rossii

16. Fy'lyuk G.M. Zarubizhny'j ta vitchy'znyany'j dosvid derzhavnoyi pidtry'mky' sil’s'kogospodars 'ky’x vy'robny'kiv/G.M. Fy'lyuk, O.V. Pimenova // Visny`k Ky’yivs`kogo nacional'nogo universy tetu imeni Tarasa Shevchenka. - 2015. - \#5 (170). - S. 6-10.

17. Finansove zabezpechennya sil's'kogospodars'ky'x pidpry'yemstv [Elektronny'j resurs] // Propozy'ciya - Golovny`j zhurnal z py`tan` agrobiznesu. - 2016. - Rezhy'm dostupu do resursu: https://propozitsiya.com/ua/finansove-zabezpechennya-silskogospodarskih-pidpriiemstv.

\section{Література.}

1. Асоціація «Укроліяпром». За оцінками USDA Україна залишається у 2020/21 MP світовим лідером 3 виробництва та експорту олії соняшникової та шроту. - Режим доступу: https://msb.aval.ua/news/?id=25886

2. Голобородько Т. В. Дослідження розвитку та інвестиційної привабливості аграрної сфери України / Т. В. Голобородько // АгроСвіт. - 2015. - № 2. - С. 30-35.

3. Духницький Б. В. Перспективи інвестування аграрного сектору України іноземними компаніями / Б. В. Духницький // Економіка АПК. - 2012. - № 10. - С. 126-131.

4. Левченко Н. В. Методи оцінювання інвестиційної привабливості сільського господарства регіонів України в контексті стратегічного планування / Н. В. Левченко, В. В. Огліх // Актуальні проблеми економіки. - 2012. - № 8. - С. 285-293. 
5. Мацибора Т. В. Світовий досвід у поліпшенні інвестиційної привабливості аграрного сектору України / Т. В. Мацибора // Економіка АПК. - 2017. - № 7. - С. 101-105.

6. Михайлов А. М. Методичні підходи та система показників визначення інвестиційного клімату в аграрному секторі економіки / А. М. Михайлов // Економіка АПК. - 2016. - № 12. - С. 76-83.

7. Молдаван Л. В. Суперечності земельної рефрорми в аграрному секторі України в контексті світової практики / Л. В. Молдаван // Економіка і прогнозування. - 2016. - № 2. - С. 148-159. - Режим доступу: http://nbuv.gov.ua/UJRN/econprog_2016_2_11

8. Мусієнко О. Л. Проблеми та шляхи підвищення інвестиційної привабливості підприємств аграрного виробництва / О. Л. Мусієнко // Стратегічні напрямки соціально-економічного розвитку держави в умовах глобалізації. - 2013. - С. 304-307.

9. Названа самая рентабельная сельхозкультура в 2019 [Електронний ресурс] // Latifundist 2019. - Режим доступу до ресурсу: https://latifundist.com/novosti/48425-nazvana-samayarentabelnaya-selhozkultura-v-2019-g

10. Нові можливості України на світовому ринку олійних культур [Електронний ресурс] // Незалежний член міжнародної мережі Baker Tilly International. - 2017. - Режим доступу до ресурсу: http://www.bakertilly.ua/news/id1189.

11. Пенцак С. П. Методичні підходи до оцінювання інвестиційної привабливості аграрних підприємств / С. П. Пенцак // Економіка та держава. - 2012. - № 5. - С. 98-100.

12. Резнік Н. П. Підвищення інвестиційної привабливості підприємств АПК - передумова залучення іноземних інвестицій / Н. П. Резнік // Формування ринкових відносин в Україні. - 2012. № 9. - С. 88-92.

13. Рудь Л. М. Інвестиційна привабливість агропромислового комплексу України: сучасний стан та перспективи [Електронний ресурс] / Л. М. Рудь, С. О. Кушнір // Проблеми системного підходу в економіці. - 2017. - Вип. 1. - С. 42-46.

14. Сидоров І. П. Методичні підходи оцінювання інвестиційної привабливості агропромислового виробництва / І. П. Сидоров // Інвестиції: практика та досвід. - 2017. - № 15. - С. 57-61.

15. Урожайность подсолнечника в Украине на 44\% больше, чем в России. Latifundist. - Режим доступу: $\quad$ https://latifundist.com/novosti/48341-urozhajnost-podsolnechnika-v-ukraine-na-44-bolshechem-v-rossii

16. Филюк Г.М. Зарубіжний та вітчизняний досвід державної підтримки сільськогосподарських виробників /Г.М. Филюк, О.В. Піменова // Вісник Київського національного університету імені Тараса Шевченка. - 2015. - №5 (170). - С. 6-10.

17. Фінансове забезпечення сільськогосподарських підприємств [Електронний ресурс] // Пропозиція - Головний журнал з питань агробізнесу. - 2016. - Режим доступу до ресурсу: https://propozitsiya.com/ua/finansove-zabezpechennya-silskogospodarskih-pidpriiemstv.

Филюк Г.М., д.е.Н., профресор,

КНУ імені Тараса Шевченка

Акуленко К.В., аспірант

КНУ імені Тараса Шевченка

\section{АНАЛІЗ ІНВЕСТИЦІЙНОЇ ПРИВАБЛИВОСТІ ПІДПРИЕМСТВ АГРОПРОМИСЛОВОГО КОМПЛЕКСУ УКРАЇНИ}

Проведено порівняння основних фрінансово-господарських показників агропромислових підприємств, які займаються вирощуванням олійних культур в Україні та визначено сучасні тенденції їх розвитку; проведено аналіз інвестиційної привабливості вітчизняних агропромислових підприємств, що займаються вирощуванням олійних культур та визначено найбільш інвестииійно привабливі вітчизняні агропромислові підприємства за результатами 
використання методу графрічного інтегрування; виявлено і проаналізовано проблеми, які спричиняють найбільш негативний вплив на рівень їх інвестиційної привабливості; проведено розрахунок комплексу показників, що визначають інвестиційну привабливість підприємства за методом графрічного інтегрування; проаналізовано агрокомпанії за трьома групами: з високою інвестиційною привабливістю, з середньою інвестиційною привабливістю та з низькою інвестиційною привабливістю; побудовано рейтинг інвестиційної привабливості вітчизняних агропромислових підприємств, які займаються вирощуванням олійних культур, у співвідношенні з різними цілями інвестора відповіднодо отриманих значень загальних інтегральних коефріцієнтів.

Ключові слова: інвестиції, інвестиційна привабливість агропромислового комплексу, інвестиційна привабливість підприємства, рейтине інвестиційної привабливості, есрективність інвестицій, показники інвестиційної привабливості, метод графрічного інтегрування, загальний інтегральний коефріцієнт, інновації.

Филюк Г.М., Д.е.Н., профрессор,

КНУ имени Тараса Шевченко

Акуленко К.В., аспирант

КНУ имени Тараса Шевченка

\section{АНАЛИЗ ИНВЕСТИЦИОННОЙ ПРИВЛЕКАТЕЛЬНОСТИ ПРЕДПРИЯТИЙ АГРОПРОМЫШЛЕНОГО КОМПЛЕКСА УКРАИНЫ}

Проведено сравнение основных фринансово-хозяйственных показателей агропромышленных предприятий, занимающихся выращиванием масличных культур в Украине и определены современные тенденции их развития; проведен анализ инвестиционной привлекательности отечественных агропромышленных предприятий, занимающихся выращиванием масличных культур и определены наиболее инвестиционно привлекательные отечественные агропромышленные предприятия по результатам использования метода графического интегрирования; выявлены и проанализированы проблемы, которые вызывают наиболее негативное влияние на уровень их инвестиционной привлекательности; проведен расчет комплекса показателей, определяющих инвестищионную привлекательность предприятия по методу графического интегрирования; проанализированы агрокомпании по трем группам: с высокой инвестиционной привлекательностью, со средней инвестиционной привлекательностью и с низкой инвестиционной привлекательностью; построено рейтине инвестиционной привлекательности отечественных агропромышленных предприятий, занимающихся выращиванием масличных культур, в соотношении с различными иелями инвестора во соответствии полученных значений общих интегральных коэффрициентов.

Ключевые слова: инвестиции, инвестиционная привлекательность агропромышленного комплекса, инвестиционная привлекательность предприятия, рейтинг инвестиционной привлекательности, эфффективности инвестиций, показатели инвестиционной привлекательности, метод графического интегрирования, общий интегральный коэфффициент, инновации. 